\title{
RELATIONSHIP BETWEEN SEXUAL INTERCOURSE AND URINARY-TRACT INFECTION IN WOMEN ATTENDING A CLINIC FOR SEXUALLY TRANSMITTED DISEASES
}

\author{
M. C. KelseY*, M. G. Mead $\dagger$, R. N. GrüneberG* and J. D. Oriel $\dagger$ \\ Departments of ${ }^{*}$ Medical Microbiology and + Genito-Urinary Medicine, \\ University College Hospital, London WCI E $6 A U$
}

THE PREVALENCE of urinary-tract infection (UTI) in women rises after the attainment of sexual maturity. Organisms can be introduced into the bladder experimentally by gentle milking of the urethra (Bran, Levison and Kay, 1972), and it is postulated that this may also result from the local 'trauma' of sexual intercourse; Kunin and McCormack (1968) found that the prevalence of UTI was higher in married women than in nuns, and Buckley, McGuckin and MacGregor (1978) showed rises in urinary bacterial counts in $30 \%$ of the intercourse episodes studied.

The present study was designed to assess the prevalence of UTI in women attending a clinic for sexually transmitted diseases and to investigate whether the onset of UTI was related to sexual intercourse.

\section{PATIENTS AND METHODS}

Women attending the department of Genito-Urinary Medicine at University College Hospital for the first time, or who had not attended during the preceding 6 months, were included in the study. A history of the patient's sexual activity that included the number of partners during the preceding year and the interval since the most recent sexual intercourse was obtained. Each patient was examined in the lithotomy position and specimens taken for the diagnosis of gonorrhoea, trichomoniasis and candidiasis by appropriate microscopy and culture (Stokes, 1975). A midstream specimen of urine (MSU) was collected after this examination.

The MSU was screened for bacteriuria on cystine lactose electrolyte-deficient (CLED) medium by the filter-paper-strip method of Leigh and Williams (1964). Urines that gave positive results in the screening test were further investigated and a pure growth of $>10^{5}$ organisms $/ \mathrm{ml}$ was considered to indicate significant bacteriuria.

\section{RESULTS}

One thousand women were included in the study; their mean age was $25 \cdot 5$ (range 18-30) years. Significant bacteriuria was found in $64(6.4 \%)$ of the MSUs; Escherichia coli was the commonest organism isolated (51), and Staphylococcus saprophyticus the second commonest (5). Only $22(34 \%)$ of the women with UTI had symptoms attributed to it. The relationship between the diagnosis of UTI and the number of sexual partners was investigated. Women with two or fewer sexual partners in the preceding year (793) were compared with those with three or more partners (204); with three patients the number of partners was not known. UTI was not significantly more common in women with three or more partners $\left(\chi^{2}=0.036 ; p>0.05\right)$ although, as expected, gonorrhoea was more common in this group $\left(\chi^{2}=11.59 ; p<0.05\right)$.

The chance of a patient having significant bacteriuria was related to the interval between her most recent sexual intercourse and her presentation at the clinic (table). Significant bacteriuria occurred most often $(11.2 \%)$ in those women who had had sexual intercourse within the preceding $24 \mathrm{~h}$, and the proportion of women seen during the 4 days after intercourse who had UTI was significantly greater than the proportion of those seen 5 days or more after intercourse $\left(\chi^{2}=7.9783 ; \mathrm{p}<0.05\right)$.

Received 6 Apr. 1979; accepted 30 Apr. 1979. 
TABLE

Interval between presentation at the clinic and most recent sexual intercourse in patients with significant bacteriuria

\begin{tabular}{l|cc}
\hline $\begin{array}{c}\text { Interval since } \\
\text { intercourse }\end{array}$ & $\begin{array}{c}\text { Number of } \\
\text { patients }\end{array}$ & $\begin{array}{c}\text { Number of } \\
\text { patients } \\
\text { with UTI (\%) }\end{array}$ \\
\hline 1 day or less & 107 & $12(11 \cdot 2 \%)$ \\
2-4 days & 245 & $21(8 \cdot 6 \%)$ \\
$5-14$ days & 348 & $16(4 \cdot 6 \%)$ \\
15 days-1 mth & 137 & $9(6.6 \%)$ \\
1 month & 127 & $4(3 \cdot 1 \%)$ \\
Not known & 36 & 2 \\
\hline
\end{tabular}

\section{Discussion}

The prevalence of UTI in the women studied was $6.4 \%$. The diagnosis of UTI based on the examination of a single MSU is not as reliable as that based on two consecutive specimens (Kass, 1956), but only one specimen was obtained because of failures to reattend the clinic and the need to treat some women on their first visit. The number of sexual partners in the preceding year is a reasonable indicator of current promiscuity; in our study this was not related to the prevalence of significant bacteriuria. UTI was, however, more often found in women who were examined soon after intercourse; this was not unexpected, because Buckley et al. (1978) found that the postcoital rise in urinary bacterial numbers usually disappeared within $48 \mathrm{~h}$. Whether the frequency of intercourse affects the prevalence of UTI remains to be determined.

\section{SUMMARY}

The prevalence of urinary-tract infection (UTI), diagnosed by examination of a single midstream urine from sexually active women was found to be $6 \cdot 4 \%$. Significant bacteriuria was most common in women who presented within $24 \mathrm{~h}$ of coitus but was not related to the number of sexual partners. UTI occurred significantly more often in women who presented within 4 days of intercourse than in women seen after a longer interval. Whether frequency of intercourse affects the prevalence of UTI remains to be determined.

We wish to thank the staff of the Department of Genito-Urinary Medicine and Medical Microbiology for their assistance in this study.

\section{REFERENCES}

Bran, J. L., Levison,.M. E. AND KaYE, D. 1972. Entrance of bacteria into the female urinary bladder. New Engl. J. Med., 286, 626.

BuCKLEY, R. M., MCGUCKIN, M. AND MACGreGoR, R. R. 1978. Urine bacterial counts after sexual intercourse. New Engl. J. Med. 298, 321.

KAss, E. H. 1956. Asymptomatic infection of the urinary tract. Trans. Ass. Am. Physns, 69, 56.

Kunin, C. M. AND MCCoRmaCK, R. C. 1968. An epidemiologic study of bacteriuria and blood pressure among nuns and working women. New Engl. J. Med. 278, 635.

LEIGH, D. A. AND Williams, J. D. 1964. Method for the detection of significant bacteriuria in large groups of patients. J. clin. Path., 17, 498.

STOKes, E. J. 1975. Clinical bacteriology, 4th ed., London. 